\title{
Ecological and economic assessment of investment activities of mining enterprises
}

\author{
Stanislav Stovpnyk ${ }^{1}$, Kostiantyn Tkachuk ${ }^{2}$, and Oleksandr Temchenko ${ }^{3 *}$ \\ ${ }^{1}$ National Technical University of Ukraine "Igor Sikorsky Kyiv Polytechnic Institute", Department of \\ Geoengineering, 115/3 Borshchahivska St., 03056 Kyiv, Ukraine \\ ${ }^{2}$ National Technical University of Ukraine "Igor Sikorsky Kyiv Polytechnic Institute", Department of \\ Environmental Engineering Department, 115/3 Borshchahivska St., 03056 Kyiv, Ukraine \\ ${ }^{3}$ Kryvyi Rih Economic Institute of Kyiv National Economic University named after Vadym Hetman, \\ Department of Economics and Entrepreneurship", 16, Medical Ave., 50000 Kryvyi Rih, Ukraine
}

\begin{abstract}
The article deals with the problematic issues and features of further development of iron ore deposits at great depths (over $400 \mathrm{~m}$ ). The necessity of wide application of innovative competitive technologies for ore mining by open method and an increase in the efficiency of mineral processing in the conditions of modern trends of sustainable development is substantiated. To solve this problem, a systematic approach is applied based on the consideration of all technological processes, taking into account the impact of mining operations on the environment as a single organizational and technological complex. It is proposed to use the Neumann-Gale model as an economic and mathematical model for assessing the investment activity of mining enterprises, which takes into account the influence of the environmental factor on the efficiency of their functioning. Approbation of the model was performed at the PJSC "Southern Mining Factory" as an example of production and economic activity. The priority measures are presented for the implementation of ecologically balanced strategies in terms of environmental protection for sustainable development at modern mining enterprises in difficult economic conditions and uncertainty of price characteristics in the markets of iron ore raw materials.
\end{abstract}

\section{Introduction}

When solving the problem of increasing the economic potential of Ukraine, a significant role is given to mining enterprises with an open method of developing deposits, which produce $85 \%$ of the volume of commercial iron ore. At the same time, the domestic iron ore base has certain features: first, it is the low quality of ores with a high content of harmful impurities; secondly, the depth of the quarries reaches more than $400 \mathrm{~m}$ and the conditions for the development of deposits are complicated, and most importantly, a small percentage of the use of innovative technologies for the extraction and processing of minerals, which causes a high energy, capital and material intensity, a negative impact on the environment. The level of competitiveness of open mining technology (OT) is

\footnotetext{
*Corresponding author: temchenko_oa@kneu.dp.ua
} 
influenced by a significant number of factors, the main of which are: the natural properties of rocks, the parameters of mining and transport equipment, taking into account a significant coefficient of wear, the system of development of mineral deposits and the level of management of mining enterprises.

The solution to the problem of improving the efficiency of mining is possible on the basis of a systematic approach to the consideration of all technological processes as a single organizational and technological set.

The beginning of the study of technological processes of open development of mineral deposits, taking into account the economic feasibility of material and energy intensity of mining production, falls on the middle of the twentieth century. In the last ten years of this problem, taking into account the need to introduce resource-saving environmentally friendly geotechnologies and monitoring the impact of investment strategies of industrial companies on the environment of a certain region, the works of domestic and foreign scientists were devoted $[1-18]$. The analysis of the work of iron ore enterprises and scientific literature indicate a low level of technological support for the competitiveness of commodity products in comparison with foreign analogues. Despite the fact that in this direction thorough theoretical and practical work is carried out, including at the state level [19], in relation to the iron ore quarries of Kryvbas, comprehensive system studies in the context of improving the final results of mining enterprises on the basis of ecological, economic and energy efficiency assessment of mining and processing of minerals, taking into account modern trends in the global economy, have not been carried out recently, which undoubtedly indicates their relevance.

\section{Problematic issues of further development of iron ore deposits}

The chosen system of its development has a significant impact on the efficiency of opencast iron ore deposits in Ukraine at considerable depths (over $400 \mathrm{~m}$ ). Each system has certain elements (the height of the ledge, the width of the working area, the length of the front of mining operations and the like), the parameters of which primarily depend on the selected types and types of mining equipment.

The analysis of the efficiency of mining allows us to assert that the possibility of using different technological processes, certain types and types of equipment and technological schemes of their interaction, certain methods of mining and overburden operations allows to form a variety of technological options for field development. At the same time, the choice of organizational and technological scheme is considered as a dynamic set of quarry equipment and mining elements, in particular, the reflection of the dynamics of the location of quarry equipment and the dynamics of changes in the elements of development and opening systems, their parameters, for example, the definition of quantitative and qualitative indicators of cargo flows. This determines the objective need for priority strategic changes in the export-oriented mining enterprises of Ukraine.

Traditional technology of open-pit mining on the deep horizons of quarries has almost exhausted its capabilities. Therefore, it is necessary to promptly introduce more progressive methods of field development, providing for the timely disposal of maximum volumes of mining waste in the mined-out areas, increasing the angles of slopes of the lower sections of the sides of the quarries, followed by their maintenance in a stable state of the pitfalls overburden, retaining pillars or the appropriate regime of open and underground works. Improvement of the ecological situation in the regions, maintenance of ore production capacities and increase of mining efficiency are possible due to the complex open-underground method of field development. It is this 
option that will allow the development of deposits to save not only the environment through the timely placement of waste mining and metallurgical production in the developed spaces, reducing the area of seized land and the full extraction of valuable components from rocks and ores, are extracted, but also reduced by $26-38 \%$ of the capital and operational expenses for the organization of a single scheme of opening, draining, ventilation, electricity supply; the creation of a unified database repair quarry and mining equipment; the creation of a common administrative apparatus.

Analysis of scientific works and practice of deep iron ore quarries shows that there are a number of characteristic problems caused by the lack of proper practical experience of mining at great depths, the lack of proven scientific and methodological recommendations for the design of mining operations in deep quarries on the basis of the impact of environmental and economic indicators on the The above points to the need to develop an effective strategy for the further development of minerals from the standpoint of ensuring the competitiveness of commodity products in the market of iron ore on the basis of appropriate methods of environmental and economic assessment of investment activities of mining enterprises.

\section{Ecological and economic assessment of investment activity of the enterprise}

Approbation of the model is feasible on the example of production and economic activity of PJSC "Southern Mining Factory". As an economic and mathematical model of investment activity evaluation, we use Neumann-Gale model, which takes into account the environmental factor. The choice of the specified enterprise is based on the fact that PJSC "Southern Mining Factory" as well as other similar mining and processing enterprises of Ukraine in the production of commodity iron-containing products carry out a large number of emissions of harmful substances into the air, pollute water and land resources, which negatively affects the environment and public health [20]. Aimed at improving the environmental condition of a balanced investment activity can bring additional profits and social benefits. The task of environmental and economic assessment of investment projects is, first of all, to scientifically determine the changes in the environment and reduce the potential losses from the extraction and processing of iron ore.

The available resources can describe the economic system of the enterprise at some point in time in the system: production, natural and labour. The possibility of transition from one state to another is given by a point-multiple coefficient $\mathrm{k}$. Thus, if at the moment $\mathrm{t}$ the state of the economic system of the enterprise is $\delta$, then at the time $t+1$ the set of States into which the system is able to pass is characterized as $k(d)$. This sequence will be called a technologically possible trajectory. For the correct assessment of the ecological compatibility of the mining enterprise production system, it is necessary to take into account the pollution caused by the production of a unit of commercial iron-containing products in the Neumann-Gale model.

We introduce a matrix of pollution intensity from production $P=\left\|P_{i j}, p_{i j}\right\|$, where $P_{i j}$ is amount of $i$-th pollution from the release of the $j$-th iron-containing product, $s$ is the number of pollution from production, $p_{i j}$ is degree of concentration of the $i$-th pollutant by the release of the $j$-th product. Then the vector of pollution will take the form:

$$
\bar{z}=P y^{T},
$$

where, $z_{i}=\sum_{j=1}^{n} P_{i j} p_{i j} y_{j}$ 
The most important environmental standard is the maximum permissible concentration the maximum amount of harmful substance per unit volume or mass, which, with daily exposure for an indefinitely long time does not cause any deviations in the body. Hygienic maximum permissible concentrations are set separately for air, water and soil. Thus, taking into account pollution, the technological process of production in the Neumann-Gale model will take the form: $z_{t}=\{\bar{\delta}: \bar{\delta}=(\bar{x}, \bar{y}, \bar{z})\} \in R_{+}^{n(t)+n(t+1)+s(t+1)}$

The model provides for the presence of a vector $\bar{x} \in R_{+}^{n(t)}, \bar{x}=A \bar{u}$, at the time $t$ that enters the state $(\bar{y}, \bar{z}) \in R_{+}^{n(t)+n(t+1)+s(t+1)}, \bar{y}=B \bar{u}$ at time $t+1$, where $A$ and $B$ are cost and output matrices of commodity products; $\bar{u}$ is vector of intensity of the types of costs.

Neumann growth rate is in equilibrium, if there is some a, technological process $(\bar{x}, \bar{y}, \bar{z}) \in Z_{t}, Z_{t} \in R_{+}^{n(t)+n(t+1)+s(t+1)}$, and also functionality $\bar{p} \in\left(R_{+}^{n(t)+n(t+1)+s(t+1)}\right)$, the following conditions are true:

$$
\begin{gathered}
a>0 . \\
\bar{p}(\bar{y}) \bar{p}(\bar{y})>0 . \\
a \bar{x} \leq(\bar{y})(\bar{z}) . \\
\bar{p}(y) \bar{p}(z) \leq a \bar{p}(x),(\bar{p}, \bar{y}, \bar{z}) \in Z .
\end{gathered}
$$

The economic growth rate $\bar{\beta}$ of the Neumann-Gale model is called the following ratio [19]:

$$
\bar{\beta}=\min _{p \geq 0} \max _{\left(x_{0} y_{0} z\right) \in Z} \frac{p(y) p(z)}{p(x)} .
$$

Taking into account the environmental factor in the Neumann-Gale model can be either active or passive. In particular, the passive nature of taking into account the environmental factor does not imply the introduction of a limitation of the vector of pollution. Instead, it is active - involves managing pollution in the technological process by introducing a restriction of the vector of pollution: $\bar{z}=\bar{z}_{n} \rightarrow, \bar{u} \leq \bar{u}_{\lim }$, where $\bar{z}_{n} \rightarrow$ is vector of ecological norms, $\bar{u}_{\lim }$ is the vector of intensity limits. The use of such a restriction can be applied only in the case of "non-dirty" production, with very environmentally friendly production. To determine the degree of environmental production it is necessary to analyze certain environmental and economic relations of the enterprise. As output characteristics for the analysis of ecological and economic relations of production can be applied:

- the main indicators of production and economic activity of the enterprise: capital stock, labour productivity;

- coefficients of environmental production: the hazard class of the production (DCP), calculated by the formula:

$$
D C P=\sum_{j=1}^{n} \frac{p_{i j}}{\rho_{i j}} a_{i},
$$

where $a_{i}$ is coefficient of bringing various contaminants to the aggregated species, characterizes the danger of pollutants; $p_{i j}$ is volume of pollution of the $i$-th species; $\rho_{i j}$ is concentration of substance in the air. 
If the value of $D C P>10^{6}$, the enterprise is the most polluting. When $D C P=10^{4}, 10^{6}-$ the second category of danger, $D C P=10^{3}, 10^{4}$ - third, with $D C P>10^{3}$ - to the lowest fourth category;

- indicators of environmental activity focused on the characterization of environmental management at the enterprise level and reflect the effectiveness of various environmental measures. Indicators of this group include:

1. The cost of production funds aimed at the protection of the environment;

2. Coefficient of efficiency of current expenditures for environmental protection measures:

$$
K_{e s}=\frac{E P C}{\sum Z_{t}}
$$

where $E P C$ is the cost of environmental protection measures [21].

Thus, according to the above indicators, it is possible to determine the degree of environmental friendliness of production, and in accordance with it to choose the active or passive type of accounting for the environmental factor in the Neumann-Gale model. The next stage of modelling is the economic assessment of environmental damage. The economic damage of the enterprise is understood as the cost expression of costs associated with the negative impact on the environment of technological emissions. In assessing the damage, it should be borne in mind that information on the amount of emissions of pollutants into the air is not always adequate. The main reason for this is the technical complexity of direct production monitoring. The model for determining the economic costs of air pollution at time $\mathrm{t}$ is as follows:

$$
\left\{\begin{array}{l}
\varphi \mu \sum_{i=1}^{s} P_{i t}^{a} a_{i} p_{i t}, p_{i t} \leq A E L_{i} ; \\
\varphi \mu \sum_{i=1}^{s} \bar{P}_{i t}^{a} a_{i} A E L_{i}+\varphi \mu \sum_{i=1}^{s} P_{i t}^{a} a_{i}\left(p_{i t}-A E L_{i}\right), p_{i t}>A E L_{i},
\end{array}\right.
$$

where $A E L_{i}$ is maximum permissible emission of substance; $P_{i t}^{a}$ is cost estimation of losses from the unit of emissions into the atmosphere of the $i$-th harmful substance, which does not exceed the limit value of AEL; $\bar{P}_{i t}^{a}$ is cost estimation of losses from the unit of emissions into the atmosphere of the $i$-th harmful substance that exceeds the limit value of $A E L ; \mu$ is coefficient taking into account the nature of the dispersion of harmful substances in the atmosphere; $\varphi$ is coefficient taking into account regional features of the territory that is subject to pollution; $a_{i}$ is coefficient of bringing various contaminants to the aggregated species, which characterizes the relative danger of pollutants [21].

We turn to the calculation of the performance indicators of the investment project, in which the costs of environmental and economic costs will be accumulated in a single cash flow.

Net Present Value (NPV). Net present value represents the difference between discounted cash flows of investments and expenses incurred in the course of project implementation. For projects with constant uniform negative environmental impact, NPV is calculated according to the model:

$$
N P V=\sum_{t=1}^{n} \frac{I \tilde{F}_{t}-O \tilde{F}_{t}-O F_{t}}{(1+r(t))^{t}}-I C_{t_{0}},
$$

where $I \tilde{F}_{t}$ is cash flow, presented in a fuzzy form; $O \tilde{F}_{t}$ is outflow of funds in a fuzzy form; $O F_{t}$ is permanent environmental costs in money terms arising as a result of the project's 
impact on the environment; $I C_{t_{0}}$ is volume of initial investments; $r(t)$ is discount rate.

In the framework of this indicator, a project can be considered profitable if NPV $>0$, loss-making if $\mathrm{NPV}<0$, and if $\mathrm{NPV}=0$, then the project can be considered neither profitable nor loss-making [20].

Forecast value $O F_{t}$ can be calculated based on the formula:

$$
O F_{t+1}^{e}=\bar{\beta} O F_{t},
$$

where $\bar{\beta}$ is economic growth rate of the model [21].

Modified Internal Rate of Return (MIRR). The modified rate of profitability or adjusted reinvestment rate internal rate of return can partially eliminate the disadvantages of the Internal Rate of Return (IRR) method associated with multiple outflows of cash and additional reinvestment. MIRR involves calculating the discount rate taking into account the total estimated value of outflows and the terminal value of inflows:

$$
M I R R=\sqrt[n]{\frac{\sum_{t=0}^{n} I \tilde{F}_{t}(1+r(t))^{n-t}}{\sum_{t=0}^{n} \frac{O \bar{F}_{t}-O F_{t}}{(1+r(t))^{t}}}}-1
$$

Profitability Index (PI). The index shows the relative profitability of the investment project per unit of initial investments:

$$
P I=\frac{\sum_{t=1}^{n} I \tilde{F}_{t}-O \tilde{F}_{t}-O F_{t}(1+r(t))^{-t}}{I C_{t_{0}}} .
$$

According to this criterion, a project can be considered profitable if $P I>1$, non-profit, if $P I<1$, but if $P I=1$, then the project is neither profitable nor loss-making.

Discounted Payback Period (DPP) is the period of time required to return the initial investment. This indicator allows to some extent to assess the riskiness of the project, as a long payback period is a risk sign:

$$
\left\{\begin{array}{c}
D P P=\min n \\
\sum_{t=1}^{n} \frac{I \tilde{F}_{t}-O \tilde{F}_{t}-O F_{t}}{(1+r(t))^{t}}=I C_{t_{0}} .
\end{array}\right.
$$

When using DPP, a project can be considered acceptable if the payback period does not exceed the established deadline.

In the next section we will move on to forecasting the performance indicators of the investment project according to the given ecological and economic model, which will allow us to assess how the volume of damage caused by the enterprise to the environment of the region will change, as well as to determine its possible profitability in the near future.

Taking into account the fact that the priority activity of PJSC "Southern Mining Factory" is to reduce environmental pollution, an investment project is proposed to replace gas cleaning systems on four agglomeration machines K-1-75, which are almost $100 \%$ physically worn, with a total investment of 837895.16 thousand UAH. The project duration is 4 years (48 months). Technical planning: construction of a modern dust and desulfurization complex on 4 sintering machines, both sintering zone of the sinter and cooling zone; the project consists of 4 main starting complexes; each of the complexes consists of 2 sections ( 1 stage of treatment - HARRICLON and second cyclones - bag filter with desulphurization). The project will reduce the formation of dust to $90 \%$, as well as sulphur emissions to $46 \%$ [22]. 
The choice of the type of environmental factor accounting is performed by the calculation of the following indicators. Indicators of production activity:

- capital stock $=802.5 \mathrm{UAH} /$ person;

- labour productivity $=2152.6$ thousand $\mathrm{UAH} /$ person.

Ecological efficiency ratio of production:

- the class of hazardous production according to the formula $(1)=244128.7$ thousand $\mathrm{UAH}$.

Indicators of environmental activity:

- the cost of productive assets aimed at environmental protection $=550$ million UAH.

- coefficient of efficiency of current expenditures for environmental protection measures $=48.3 \%$.

Based on the data obtained, we have hazard class DCP $>10^{6}$, indicating the first, the most dangerous and polluting level of environmental damage. Therefore, the considered enterprise on efficiency coefficient of the current expenses for nature protection actions during the last years is at rather low level.

In accordance with the results of the company's activities, we conclude that in the framework of the Neumann-Gale model, the environmental factor should be passive in the calculations without the need to introduce restrictions on the pollution vector. Next, we calculate the growth rate of the enterprise within the Neumann-Gale model, taking into account the fact that the enterprise provides one method of producing iron ore sinter. In accordance with the indicators of air pollution three types of harmful substances (dust, carbon monoxide and sulphur oxide) from the production of agglomerate form matrix. For further calculations.

We introduce the following matrixes of cost and output:

$$
A=\left(\begin{array}{c}
229748.3 \\
67702 \\
3736 \\
1119690.8 \\
60267.6 \\
48006.8
\end{array}\right) ; \quad B=\left(\begin{array}{c}
518.35 \\
492.16 \\
417.02 \\
139.95 \\
15304.63 \\
61969
\end{array}\right) \text {, }
$$

where $A_{1}$ is expenditures of sintering ore, ths. UAH; $A_{2}$ is costs of limestone, ths. UAH; $A_{3}$ is costs of gratings, ths. UAH; $A_{4}$ is consumption of solid fuel, ths. UAH; $A_{5}$ is costs of gaseous fuel, ths. UAH; $A_{6}$ is electricity costs, ths. $\mathrm{UAH} ; B_{1}$ is volumes of sintering ore, ths. $\mathrm{UAH} ; B_{2}$ is volumes of limestone, ths. ton; $B_{3}$ is volumes of gratings, ton; $B_{4}$ is volumes of solid fuel, ths. ton; $B_{5}$ is volumes of gaseous fuel, ton; $B_{6}$ is electricity volumes, ths. $\mathrm{kW}$ per hour.

We find the vector of the intensity of the production of iron-ore agglomerate using the following limitation:

$$
\left\{\begin{array}{c}
\bar{p} B \bar{u} \rightarrow \max ; \\
A \bar{u} \leq S,
\end{array}\right.
$$

where $S$ is inventory of products of industrial and technical purpose, thousand $\mathrm{UAH} ; \bar{u}$ is vector of iron ore agglomerate production intensity; $\bar{p}$ is unit price of a resource for the production of iron ore agglomerate, UAH/unit.

Having solved the optimization problem we have full use of the reserves of 604210 thousand UAH and the intensity vector $\bar{u}=(2.629)$.

Consequently, we have matrices of growth rates: 


$$
\begin{aligned}
& \bar{x}=A \bar{u}=\left(\begin{array}{llllll}
604210 & 178046.8 & 9825.19 & 294466.9 & 158496.5 & 126252
\end{array}\right) \\
& \bar{y}=B \bar{u}=\left(\begin{array}{llllll}
1363.19 & 1294.32 & 1096.71 & 368.05 & 40249.33 & 162970.9
\end{array}\right) ; \\
& \bar{z}=P y=\left(\begin{array}{lllll}
5.52 & 0.894 & 0.056
\end{array}\right) .
\end{aligned}
$$

We calculate the economic growth rate of a model by the formula (6):

$$
\bar{\beta}=\frac{162970.9 \cdot 5.52}{604210}=1.489 \text {. }
$$

The next step is to make a monetary assessment of losses from atmospheric air pollution. The main pollutants of the air of the process of making iron ore agglomerate at PJSC "Southern Mining Factory" include dust, carbon monoxide and sulphur oxide, whose concentrations are presented in Table 1.

Table 1. Composition of air pollutants from agglomeration of iron ores at PJSC "Southern Mining Factory", 2016 year.

\begin{tabular}{|c|c|c|c|c|}
\hline Pollutant & $\begin{array}{c}\text { Concentration } \\
\text { of substance } \\
(p), \mathrm{mg} / \mathrm{m}^{3}\end{array}$ & $\begin{array}{c}\text { Background } \\
\text { concentration } \\
\left(C_{f i}\right), \mathrm{mg} / \mathrm{m}^{3}\end{array}$ & $\begin{array}{c}\text { Coefficient of ecological- } \\
\text { economic hazard of a } \\
\text { substance }(a)\end{array}$ & $\begin{array}{c}\text { Maximum } \\
\text { permissible } \\
\text { concentration } \\
(C M A i), \mathrm{mg} / \mathrm{m}^{3}\end{array}$ \\
\hline Dust & 0.8 & 0.07 & 100 & 0.15 \\
\hline $\begin{array}{c}\text { Carbone } \\
\text { monoxide }\end{array}$ & 2 & 1.8 & 1 & 3 \\
\hline $\begin{array}{c}\text { Sulphur } \\
\text { oxide }\end{array}$ & 0.012 & 0.01 & 16.5 & 0.05 \\
\hline
\end{tabular}

Source: author's version using [23].

It is known that the value of the coefficient that is tailored to pollute the atmosphere $\varphi=1.25 ; H=8.8 \mathrm{~m}$ is the height of the emission source; $t_{1}=80^{\circ} \mathrm{C}$ is temperature emission; $\omega_{0}=3.87 \mathrm{~m} / \mathrm{s}$ is velocity ejection; $D=0.15 \mathrm{~m}$, the size of the mouth of the emission source, $t_{2}=8.5^{\circ} \mathrm{C}$ is average temperature of the environment; $A=200$ is coefficient of stratification (located in Ukraine sources with a height of less than $200 \mathrm{~m}$ in the zone from $50^{\circ}$ to $52^{\circ}$ North latitude); $F=1$ - dimensionless coefficient that takes into account the settling velocity of harmful substances in atmospheric air; $\eta=1$ is dimensionless coefficient taking into account the influence of the terrain of the Kryvyi Rih region.

The maximum permissible emission (AEL) of substances into the atmosphere is calculated on the basis of the following equation and its individual indicators:

$$
\begin{gathered}
A E L=\frac{\left(C_{M A i}-C_{f i}\right) H^{2}}{A \cdot F \cdot m \cdot n \cdot \eta} \sqrt[3]{V_{1} \Delta T} . \\
m=\frac{\Delta T=t_{1}-t_{2}=23.3^{\circ} \mathrm{C} .}{0.67+0.1 \cdot \sqrt{f+0.34 \cdot \sqrt[3]{f}}}=1.008 . \\
f=1000 \frac{\omega_{0}^{2} D}{H^{2} \cdot \Delta T}=0.405 .
\end{gathered}
$$

The air flow rate is calculated according to the following formula:

$$
V_{1}=\frac{\pi D^{2}}{4} \omega_{0}=0.068 \mathrm{~m}^{3} / \mathrm{sec} \text {. }
$$




$$
\begin{gathered}
V_{m}=0.65 \cdot \sqrt[3]{\frac{V_{1} \Delta T}{H}}=0.533 . \\
n=0.532 \cdot \mathrm{Vm}^{2}-2.13 \cdot V_{m}+3.13=2.146 .
\end{gathered}
$$

Therefore, substituting in formula (16) the corresponding calculations of formulas (17, $18,20,22)$ we obtain the following AEL and data for calculating the costs of air pollution (Table 2).

Table 2. Data for the calculation of the costs of atmospheric air pollution by PJSC "Southern Mining Factory" activities, 2016 year.

\begin{tabular}{|l|c|c|c|c|}
\hline \multicolumn{1}{|c|}{ Pollutant } & $\begin{array}{c}\text { Actual release } \\
(p), \mathrm{g} / \mathrm{sec}\end{array}$ & $\begin{array}{c}\text { Maximum permissible } \\
\text { emission }(A E L), \mathrm{g} / \mathrm{sec}\end{array}$ & $\begin{array}{c}P^{a^{\prime}}(\text { at } p \leq A E L), \\
\mathrm{UAH} / \text { ton }\end{array}$ & $\begin{array}{c}P^{a^{\prime \prime}}(\text { at } p \geq A E L), \\
\mathrm{UAH} / \mathrm{ton}\end{array}$ \\
\hline Dust & 0.32 & 0.013 & 3611.61 & 81393.4 \\
\hline $\begin{array}{l}\text { Carbone } \\
\text { monoxide }\end{array}$ & 0.165 & 0.193 & 83.07 & 101.86 \\
\hline $\begin{array}{l}\text { Sulphur } \\
\text { oxide }\end{array}$ & 0.056 & 0.006 & 538.13 & 641.2 \\
\hline
\end{tabular}

Source: author's version using [24].

As you can see, emissions of dust and sulphur oxide exceed the maximum permissible norm. At the same time, in index (a) they have the most dangerous properties (the coefficients of danger, respectively, 100 and 16.5). Substituting the obtained values into formula (9), we obtain a monetary loss $\left(O F_{t}^{e}\right)$ in the amount of $8298120 \mathrm{UAH}$ per month [20].

Thus, the prospects for improving investment activities at PJSC "Southern Mining Factory" are largely determined by the possibility of introducing innovative technologies for the extraction and processing of iron ore raw materials and increasing the competitiveness of the enterprise on this basis, which is provided, first of all, by the observance of environmentally friendly production. Of course, this increases the value of the invested capital for the potential investor by reducing the amount of environmental payments and environmental tax at the enterprise, and will also provide an additional positive result in the form of a social effect.

In order to realize these prospects, it is necessary to pay attention to the development of an effective state investment policy, according to which mining enterprises will carry out the formation of an investment program, the development of projects for the selection and implementation of priority ways to expand and update production capacity, the introduction of environmental sustainable development strategies and strengthening the competitive advantages of domestic commodity products in general in the foreign market of iron ore.

\section{Conclusions}

Taking into account the above, promising areas for further efficient operation of iron ore deposits of Ukraine in an open way is:

- development and operational implementation of sound environmental environmentally balanced investment strategies for the timely transition to a combined open-underground method of mining a certain field;

- using underground excavations for transportation of rock mass on dump trucks, as well as determining feasibility of use of modern diesel-trolleytruck and inclined career automotive lifts and inclined mining conveyor or skip hoists to provide the comprehensive 
mining of deep horizons steeply sloping fields in the near future;

- introduction in the near future of mobile crushing complexes in the quarry and internal dumping;

- implementation of energy saving due to the widespread introduction of resource and energy saving measures into the technological process of ore extraction and processing, including by increasing the mowing angle of the working and non-working sides of the quarry;

- technical re-equipment of mining enterprises and the creation of an effective system of ore averaging, as well as the formation of stationary and temporary transshipment points on the deep horizons of the quarry;

- making informed management decisions and measures based on the calculation of economic indicators as key factors for the successful socio-economic development of mining enterprises with the determination of the feasibility of technological changes in production for certain situations in the market of iron ore.

Therefore, management of strategic changes at the mining enterprises of Ukraine in the conditions of trends of sustainable development and preservation of negative trends of economic instability and uncertainty can be provided at the expense of the decision of earlier specified scientific and technical problems of effective production of iron ores by innovative technical re-equipment of technological complexes on the basis of an ecological and economic assessment of their application, formation of optimum technological schemes of work of the equipment on perspective and operational intervals of management, reduction of energy intensity of production and rational use of all resources to determine the energy efficiency of mining production according to higher international standards of the market and consumers qualitative and price characteristics iron-containing products.

This work was conducted within the projects "Provision of balanced nature management, reduction of energy intensity of production and increasing the level of environmental safety of enterprises on the basis of analysis and synthesis of optimal geotechnological processes" (State registration No. 0111U010300).

\section{References}

1. Bardas, A., \& Bogach, K. (2013). Scientific and technical principles of implementing resourcesaving ecologically safe geotechnologies. Stalyy rozvytok ekonomiky, (1), 177-180.

2. Vyshnyts'ka, O. (2009). Environmental investments: essence, classification, principles and directions of implementation. Visnyk Sumskoho Derzhavnoho Universytetu, (2), 51-58.

3. Dixon, J., \& Pajiola, S. (2012). Economic analysis and environmental impact assessment. Moskva: Vita-Press.

4. Izmaylov, Ya. (2008). Improvement of the accounting of capital investments in the ecological direction at industrial enterprises. Formuvannia rynkovoi ekonomiky, (19), 327-335.

5. Klimenko, O. (2010). Instruments of environmentalization of investment activity at the stages of its implementation. Visnyk Khmelnytskoho Natsionalnoho Universytetu, 2(2), 198-203.

6. Kubay, D. (2012). State regulation of ecological investment in Ukraine. Lviv: Lvivskyi natsionalnyi universytet im. I. Franka.

7. Lozyns'kyy, I., \& Tryfonova, O. (2010). Ecological and economic management of mining enterprises. Dnipropetrovsk: Natsionalnyi hirnychyi universytet.

8. Sadekov, A. (2004). Mechanisms of environmental - economic management of an enterprise. Kharkiv: Idinzhek.

9. Khal'fiyev, R., \& Magaril, Ye. (2009). Issues of environmental and economic assessment of investment projects. Vestnik Ural'skoho Gosudarstvennogo Technicheskogo Universiteta, (2), 81-88. 
10. Kostenko V., \& Shaforostova M. (2009). Perfection of economic activities of the mining enterprises on the basis of the balanced technological, ecological and economic development. Procedia Earth and Planetary Science, (1), 304-308. https://doi:10.1016/j.proeps.2009.09.048

11. Romeiro, A.R. (2012). Sustainable development: an ecological economics perspective. Estudos Avançados, 26(74), 65-92. https://doi:10.1590/s0103-40142012000100006

12. Kokko, K., Buanes, A., Koivurova, T., Masloboev, V., \& Pettersson, M. (2015). Sustainable mining, local communities and environmental regulation. Peoples, Economies and Politics, 2(1), 50-81.

13. Alves, W., Ferreira, P., Colombo, C., \& Portela, C. (2017). Environmental strategies for the mining sector: evidences from a Brazilian company. REBRAE, Curitiba, 10(2), 186-203. https://doi.org/10.7213/rebrae.10.002.A001

14. Novoselov, A., Potravny, I., Novoselova, I., \& Chávez Ferreyra, K. (2018). The Mechanism to Implement Environmental Investment Projects on the Basis of Equity Financing. Ekonomika regiona, 14(4), 1488-1497. https://doi.org/10.17059/2018-4-33

15. Osipov, V., Kuzubov, A., Shashlo, N., \& Rudenko, A. (2018). Architecture of Development Process Model for Financial and Investment Strategy of Industry Enterprise Structures. TOJDAC, Special Edition, 482-493. doi:10.7456/1080MSE/157

16. Damineva, R., \& Yevtushenko E. (2018). Management of Ecological Innovation. Social \& Behavioural Sciences, (50), 300-304. https://dx.doi.org/10.15405/epsbs.2018.12.37

17. Terentiev, O., Tkachuk, K., Tverda, O., \& Kleshchov, A. (2018). Mathematical model of the reverse water postpurification at mining enterprises when using electromagnetic focusing of contaminants. Eastern-European Journal of Enterprise Technologies, 1(10(91)), 10-16. https://doi.org/10.15587/1729-4061.2018.122000

18. Temchenko, O. (2014). Study of the open-cast mining technology parameters influence on the efficiency of iron-ore deposits development. Naukovyi Visnyk Natsionalnoho Hirnychoho Universytetu, (1), 16-21.

19. Pro skhvalennia Kontseptsii Derzhavnoi tsilovoi naukovo-tekhnichnoi prohramy rozvytku ta reformuvannia hirnycho-metalurhiinoho kompleksu Ukrainy na period do 2020 roku. (2016). Retrived from https://www.kmu.gov.ua/ua/npas/248779815

20. Sobakins'kykh, R., \& Temchenko, O. (2018). Estimation of efficiency of investment activity of the enterprise and perspective directions of its provision. Kryvyi Rih. http://dspace.kneu.dp.ua:8080/jspui/handle/123456789/188

21. Borlakova, A. (2014). Modeling of ecological and economic evaluation of investment projects. Moskva.

22. Annual Financial Reports of PJSC "Southern Mining Factory". (2016). http://www.ugok.info/upload/iblock/e9d//

23. Environmental passport of the city of Kryvyi Rih. Retrived from http://kr.gov.ua/ua/osxfile/pg/190117418982655 n 1o/14-65686226.doc

24. Nikitin, A., \& Arbuzov, V. (1957). Agglomeration of iron ores. Moskva: Metallurgizdat. 